\title{
BEYOND SUBSISTENCE: FOOD AND FOODWAYS IN INDO-PACIFIC ARCHAEOLOGY
}

\author{
Michelle S. Eusebio and Amy Jordan
}

University of Florida; University of Washington

Emails: meusebio@ufl.edu, ajordan2@u.washington.edu

\section{INTRODUCTION}

The following papers in this issue were presented in a session entitled Beyond Subsistence: Food and Foodways in Indo-Pacific Archaeology, organized during the $20^{\text {th }}$ Indo-Pacific Prehistory Association (IPPA) Congress in Siem Reap, Cambodia. "Foodways" is defined as the "production and procurement, processing, cooking, presentation, and eating" (or consumption) of food (Atalay and Hastorf 2006: 283), including disposal of food refuse and associated material culture (Twiss 2012). This session was conceived during the European Association of Southeast Asian Archaeologists (EurASEAA) $14^{\text {th }}$ International Conference in Dublin. We agreed that the treatment of food in Southeast Asian archaeological research is mostly in terms of identifying subsistence patterns, which did not adequately represent our interests or the variety of the archaeological evidence. The major themes associated with subsistence are the environment, dispersal of people, and foraging-farming transition (Eusebio 2012). Extending to the Indo-Pacific area, much of the food-related literature tends to be biased towards the production (agriculture, horticulture, animal husbandry) and procurement (hunting-gathering/foraging) of food as subsistence strategies; these are in contrast to a few works that delve into the holistic cultural meanings behind what was eaten or how and why it was prepared or selected.

Beyond identifying subsistence patterns, the chaine opératoire (sensu Leroi-Gourhan 1983) of subsistence is more concisely called "foodways" (sensu Jones 2002). Thus, realizing that "foodways" is the more appropriate search term, one would notice that there is still a paucity of results, with some notable exceptions (e.g., Lape 2000, 2004, 2005; Jones 2009, 2011; Jones and Quinn 2010). One only needs to give a cursory look at food-related works in different geographical regions of Indo-Pacific area to observe the trends mentioned above. Little information can be found about research into foodways beyond subsistence from the Indo-Pacific area that is comparable to the research on the cuisine of the European Neolithic and Bronze Age. A notable example is the discussion of cuisine of Neolithic and later India by Fuller (2005).

This begs the questions: Are there really so few works on food beyond subsistence in Indo-Pacific Archaeology? Or is there actually more research being conducted that only needs an appropriate venue for its presentation or publication? Thus, we decided to organize a session on food and foodways for the Indo-Pacific Prehistory Association Conference in Siem Reap, Cambodia. After all, Twiss (2012:378) noted that "there is ample room for research on food and social diversity in a wide variety of regions and time periods that are as yet underserved in the literature, such as central, eastern, and southeastern Asia; Australia; Africa (especially outside of its northeast); the early Islamic Middle East; and postcontact Oceania." Except for Africa and Middle East, the rest of the areas that Twiss (2012) mentioned are part of Indo-Pacific area.

The archaeological record of the Indo-Pacific area is rich with the remnants of food preparation and consumption, such as plant and animal remains as well as ceramics, lithics, and other materials. However, these discarded food and material culture remains generally are only used to address past subsistence, production, and economy (Parker-Pearson 2003). There are an exception of a few researchers (e.g., Chase 2012; Junker 2001; Junker and Niziolek 2010; Smith 2006) that tackled food preparation and consumption. We are confident that a more holistic picture of foodways in Indo-Pacific archaeology can be completed by examining ways of processing food, as well as cooking and serving food. This session gathered papers that deal directly with food processing, cooking, serving, and consumption; based on bioarchaeological remains (humans, animals, and plants) and/or material culture (ceramics, lithics, etc.); as well as papers that discuss food beyond its subsistence role. It also provided an alternative for the researchers who are not necessarily addressing paleoenvironments, dispersal of people, and foragingfarming transition, but who have different thematic, theoretical, and technical approaches for investigating the biological and material cultural remains of foodways in their Indo-Pacific archaeological research.

We invited presentors through a variety of channels and were overwhelmed by their positive responses, many of expressed satisfaction that this topic was being broached for the first time at an IPPA meeting. From the two sessions we originally envisioned, it was necessary to request a third. It is clear that there is substantial interest and activity in foodway research despite the paucity of published material.

The final session had 16 presentations with three on ethnoarchaeological approaches (Gandhi 2014; Taniardi 
and Kasnowihardjo 2014; Yankowski 2014); four on food residues in ceramics (Eusebio 2014; Jordan 2014; Kwak 2014; Nishida et al. 2014), one on combined ethnohistorical and archaeological approach on precontact foodways (Moore 2014), two on archaeobotany (Ceron and Rabett 2014; Fuller 2014), one on plant and animal residues on stone tools (Lentfer 2014), two on zooarchaeology (Campos 2014; Manalo 2014), one on stable isotope approach on human remains (King et al. 2014a), as well as two on social archaeological approaches (Jones 2014; Lentfer and Specht 2014).

Several of these sixteen papers are included in this issue through the enthusiasm of the presentors to submit their papers for one of the pioneering volumes of Journal of Indo-Pacific Archaeology (some of the remaining presentors had their works already submitted to other venues for publication). Three papers in this volume involve ethnographic and ethnoarchaeological approaches to draw insights for understanding the archaeological record and the past. Taniardi and Kasnowihardjo demonstrated the long-term settlement and subsistence pattern at the Ranu Grati Lake site in Indonesia through archaeological and ethnographic approaches, where the utilization of the lake does not only involve dependence on fishing but also the continuous bond between the people and the lake through maintenance and ceremonies. Through her ethnoarchaeological work with the Galos people in Northeast India, Gandhi showed that environmental conditions and perishable material culture involved in their foodway practices posed challenges to archaeological recovery and interpretation of past lifeways in the region. Yanskowski and Kerdsap shared their ethnoarchaeological work in northeast Thailand on salt and salt-fermented food products, which are not only important commodities but also markers of pride and identity in Southeast Asia, as well as its implication for the archaeology of the region.

Three papers include analyses of microscopic and molecular food remains on ceramics to identify foodways. Eusebio provided a preview on how the combined technofunctional and organic residue approaches on archaeological, ethnographic, and experimental pottery can provide insights on the foodways of prehistoric Southern Vietnam. Kwak and Marwick presented their preliminary findings from utilizing organic residues as proxies to address subsistence and culinary practices in prehistoric central Korea, where bioarchaeological remains do not preserve due to the high acidity of sediment. Jordan identified differential responses to European colonization in the Banda Islands, Indonesia based on an examination of faunal, ceramic, and starch grain residue data. Another paper by Manalo is focused on the examination of cut marks on faunal material from Ille cave site, Northern Palawan, Philippines to assess past subsistence and food processing strategies of the occupants during the transition from Late Pleistocene to Early Holocene.

Two papers are synthetic works on two groups of islands in the Pacific. Moore provided a synthesis of ethnohistorical and archaeological findings (analyses of plant, animal, and residue remains; features, radiocarbon dates) to paint a preliminary picture of the precontact foodways in the Marianas Islands. Jones showed what it means to be Fijian, past and present, by exploring foodways through the lens of materiality with the analysis of zooarchaeological remains and associated material culture.

We were very pleased with the outcomes of this session in terms of the presentations and interests of the audience, which motivated us to further pursue this as a themed issue in JIPA. We look forward to an improved availability of literature on foodways and cuisine in the archaeologies of Indo-Pacific area. By moving beyond subsistence to foodways, we can explore the human behavior behind social diversity- including identity in terms of economic, status, ethnic, gender, and religious distinctions (after Twiss 2012:357) - across space and time in the Indo-Pacific area.

\section{ACKNOWLEDGMENTS}

We would like to thank the organizing committee of the IPPA 2014 meetings headed by Dr. Ian Lilley for approving and helping promote the session on Food and Foodways in Indo-Pacific Archaeology. We also thank our colleagues who presented and shared their works with the IPPA community, other colleagues who recommended potential presentors, who were our audience, and those who peer-reviewed the works included this issue.

\section{REFERENCES}

Atalay, S. and C.A. Hastorf. 2006. Food, Meals, and Daily Activities: Food Habitus at Neolithic Catalhöyük. American Antiquity 71: 283-319.

Campos, F. 2014. Fish Consumption and the Utilization of Aquatic Resources in Neolithic Vietnam. Paper presented at the 20th Congress of the Indo-Pacific Prehistory Association, Siem Reap.

Ceron, J. and R. Rabett. 2014. Plant Food Sources: The Macrobotanical Assemblage of Hang Boi and Hang Trong Caves. Paper presented at the 20th Congress of the IndoPacific Prehistory Association, Siem Reap.

Chase, B. 2012. Crafting Harappan Cuisine on the Saurashtran Frontier of the Indus Civilization. In S.R. Graff and E. Rodriguez-Alegria (eds.), The Menial Art of Cooking: Archaeological Studies of Cooking and Food Preparation, pp. 145-171. Boulder: University Press of Colorado.

Eusebio, M.S. 2012. Looking at government agencies to see how archaeology can be relevant to contemporary concerns: the Department of Agriculture of the Philippines in relation to ancient foodways. Paper presented at the European Association of Southeast Asian Archaeologists 14th International Conference, Dublin.

Eusebio, M.S. 2014. Foodways through Ceramics in Southeast Asia: A View from Southern Vietnam. Paper presented at the 20th Congress of the Indo-Pacific Prehistory Association, Siem Reap.

Fuller, D.Q. 2005. Ceramics, Seeds and Culinary Change in Prehistoric India. Antiquity 79: 761-777.

Fuller, D.Q. 2014. Sticky rice or Chapatis? A culinary Movius line and its impact on crop choice, crop variety diversification, and archaeobotanical evidence. Paper presented at 
the 20th Congress of the Indo-Pacific Prehistory Association, Siem Reap.

Gandhi, B.D. 2014. Indigenous Foodways of the Galos: A Challenge to Archaeology. Paper presented at the 20th Congress of the Indo-Pacific Prehistory Association, Siem Reap.

Jones, M. 2002. Eating for Calories of for Company? Concluding Remarks on Consuming Passions. In P. Miracle and N. Milner (eds.), Consuming Passions and Patterns of Consumption, pp. 131-136. McDonald Institute for Archaeological Research, Cambridge.

Jones, S. 2009. Food and Gender in Fiji: Ethnoarchaeological Explorations. Lanham: Lexington Books.

Jones, S. 2011. Contemporary subsistence and foodways in the Lau Islands of Fiji: An ethnoarchaeological study of nonoptimal foraging and irrational economics. In U. Albarella and A. Trentacoste (eds.), EthnoZooarchaeology: The Past and Present of Human-Animal Relationships, pp. 7381. Oxford: Oxbow Books.

Jones, S. 2014. Eating Ethnicity: An Exploration of Fijian Foodways in the Archaeological Past. Paper presented at the 20th Congress of the Indo-Pacific Prehistory Association, Siem Reap.

Jones, S. and R. Quinn. 2010. Waitui Kei Vanua: Interpreting Sea- and Land-Based Foodways in Fiji. In A.M. VanDerwarker and T.M. Peres (eds.), Integrating Zooarchaeology and Paleoethnobotany: A Consideration of Issues, Methods, and Cases, pp. 135-172. New York: Springer.

Jordan, A. 2014. Spice Island Stew: Creolization of foodways on colonial era nutmeg plantations, Maluku Province, Indonesia. Paper presented at the 20th Congress of the IndoPacific Prehistory Association, Siem Reap.

Junker, L.L. 2001. The Evolution of Ritual Feasting Systems in Prehispanic Philippine Chiefdoms. In M. Dietler and B. Hayden (eds.), Feasts: Archaeological and Ethnographic Perspectives on Food, Politics, and Power, pp. 267-310. Washington: Smithsonian Institution Press.

Junker, L.L. and L. Niziolek. 2010. Food Preparation and Feasting in the Household and Political Economy of PreHispanic Philippine Chiefdoms. In E.A. Klarich (ed.), $A n-$ cient Kitchens: New Directions in the Study of Daily Meals and Feasts, pp. 17-53. Boulder: University Press of Colorado, Boulder.

King, C.L., N. Tayles, C. Macpherson, and J. Newton. 2014a. Beyond Subsistence: Prehistoric Diet and Society in the Upper Mun River Valley. Paper presented at the 20th Congress of the Indo-Pacific Prehistory Association, Siem Reap.

Kwak, S. 2014. What did they cook?: Culinary practice and pottery usage in the central part of the prehistoric Korean Peninsula. Paper presented at the 20th Congress of the Indo-Pacific Prehistory Association, Siem Reap.

Lape, P.V. 2000. Political Dynamics and Religious Change in the Late Pre-Colonial Banda Islands. World Archaeology 32: 138-155.

Lape, P.V. 2004. The Isolation Metaphor in Archaeology. In S.M. Fitzpatrick (ed.), Voyages of Discovery: The Archaeology of Islands, pp. 223-232. Westport: Praeger.

Lape, P.V. 2005. Archaeological Approaches to the Study of Islam in Island Southeast Asia. Antiquity 79: 829-836.
Lentfer, C. 2014. Detection of plant and animal residues on stone tools from Liang Bua, Flores, Indonesia and implications for Hominin behavior. Paper presented at the 20th Congress of the Indo-Pacific Prehistory Association, Siem Reap.

Lentfer, C. and J. Specht. 2014. Beyond the staples: the past role of nuts and fruits in creating and mediating social relations in the western Pacific Islands. Paper presented at the 20th Congress of the Indo-Pacific Prehistory Association, Siem Reap.

Leroi-Gourhan, A. 1983. Gesture and Speech. MIT Press, Cambridge, MA.

Manalo, K.A. 2014. Late Pleistocene-Early Holocene Subsistence in Ille Cave: Faunal cutmarks as an alternative method on determining food processing. Paper presented at the 20th Congress of the Indo-Pacific Prehistory Association, Siem Reap.

Moore, D. 2014. Mariana Islands Foodways: A Taste of History. Paper presented at the 20th Congress of the Indo-Pacific Prehistory Association, Siem Reap.

Nishida, Y., O. Craig, C. Heron, and H. Saul. 2014. Pots for cooking, pots for processing: Foodcrust analysis of Jomon pottery. Paper presented at the 20th Congress of the IndoPacific Prehistory Association, Siem Reap.

Parker-Pearson, M. 2003. Food, Culture and Identity: An Introduction and Overview. In M. Parker Pearson (ed.), Food, Culture and Identity in the Neolithic and Early Bronze Age, pp. 1-30. Oxford: Archaeopress.

Smith, M. L. 2006. The Archaeology of Food Preference. American Anthropologist 108: 480-493.

Taniardi, P.N. and G. Kasnowihardjo. 2014. Subsistence Pattern in Ranu Grati Lake Site. Paper presented at the 20th Congress of the Indo-Pacific Prehistory Association, Siem Reap.

Twiss, K.C. 2012. The Archaeology of Food and Social Diversity. Journal of Archaeological Research 20: 357-395.

Yankowski, 2014. "Please pass the salt" An ethnoarchaeological study of salt production, use, and trade in Northeast Thailand. Paper presented at the 20th Congress of the IndoPacific Prehistory Association, Siem Reap. 